\title{
Dissecting the role of cyclic nucleotides in memory processes
}

Citation for published version (APA):

Argyrousi, E. K. (2019). Dissecting the role of cyclic nucleotides in memory processes. [Doctoral Thesis, Maastricht University]. Maastricht University. https://doi.org/10.26481/dis.20190221ea

Document status and date:

Published: 01/01/2019

DOI:

10.26481/dis.20190221ea

Document Version:

Publisher's PDF, also known as Version of record

\section{Please check the document version of this publication:}

- A submitted manuscript is the version of the article upon submission and before peer-review. There can be important differences between the submitted version and the official published version of record.

People interested in the research are advised to contact the author for the final version of the publication, or visit the DOI to the publisher's website.

- The final author version and the galley proof are versions of the publication after peer review.

- The final published version features the final layout of the paper including the volume, issue and page numbers.

Link to publication

\footnotetext{
General rights rights.

- You may freely distribute the URL identifying the publication in the public portal. please follow below link for the End User Agreement:

www.umlib.nl/taverne-license

Take down policy

If you believe that this document breaches copyright please contact us at:

repository@maastrichtuniversity.nl

providing details and we will investigate your claim.
}

Copyright and moral rights for the publications made accessible in the public portal are retained by the authors and/or other copyright owners and it is a condition of accessing publications that users recognise and abide by the legal requirements associated with these

- Users may download and print one copy of any publication from the public portal for the purpose of private study or research.

- You may not further distribute the material or use it for any profit-making activity or commercial gain

If the publication is distributed under the terms of Article $25 \mathrm{fa}$ of the Dutch Copyright Act, indicated by the "Taverne" license above, 


\section{Chapter 8}

Summary 
The literature background and the main rationale of the thesis are introduced in chapter $\mathbf{1 .}$

The current literature summarized in chapter 2 suggests that targeting several components of the cAMP or the cGMP pathway could enhance synaptic plasticity and memory formation. Despite the overwhelming body of literature showing a pro-cognitive action in upregulating either cAMP or cGMP signaling, it is still controversial which components should be targeted in memory-related diseases. In this respect, pharmacological interventions like PDE inhibitors seem to represent a more balanced approach in comparison to genetic interventions that lead to complete depletion of a molecule. Additionally, a possible strategy to reduce the unwanted side effects of pharmacological agents could be via combination of sub-optimal doses of drugs that act on different cascades. Finally, we suggest that application of optical and genetic techniques for better understanding of the complex mechanisms participating in the spatiotemporal regulation of cyclic nucleotide signaling, and implementation of computational models for integrating experimental data would be important assets in the development of new therapeutic strategies.

In chapter 3 we summarize studies regarding the role of glutamatergic signaling in object recognition and object location memory. As in every system, balance in the action of glutamatergic transmission is the key in neuronal functioning, since excessive activation via agonists or blockage via antagonists impairs memory. Nevertheless, the latter studies revealed that activation of different types of receptors is responsible for glutamatergic signaling at different mnemonic phases. Importantly, it was shown that inhibition of glutamatergic neurotransmission by antagonist or negative modulators could ameliorate cognitive deficits in pathological conditions characterized by excitotoxicity, like Alzheimer's disease. Notwithstanding, administration of agonists for the glycine-binding site of NMDARs and positive modulators of AMPARs and mGluRs could have pro-cognitive effect in healthy animals. Collectively, these results suggest that pharmacological agents acting on glutamatergic system could have promising clinical applications.

In chapter 4 we showed that administration of vardenafil or rolipram at the acquisition phase of spatial memory could compensate against natural forgetting occurring after $24 \mathrm{~h}$ in mice. Importantly, at the consolidation phase we were able to distinguish the action of these drugs. In particular, memory enhancement was achieved when vardenafil was administrated at the early consolidation phase or when rolipram was given at the late consolidation phase. 
Subsequently, we assessed whether the pro-cognitive effect of the above inhibitors could be related to changes in AMPAR dynamics. In short, upregulation of cGMP signaling during the acquisition and early consolidation phase via vardenafil administration improved long-term memory and this phenomenon could be explained by increased surface expression of GluA1and GluA2-containing AMPARs. Additionally, although administration of rolipram at the acquisition and late consolidation phase enhanced long-term memory in mice tested in the object location test, the underlying mechanism does not involve changes in AMPAR trafficking or synthesis.

In the study presented in chapter $\mathbf{5}$ we showed that increase in NO levels could protect against oTau-induced suppression of LTP via activation of sGC that in turn stimulates production of cGMP and subsequent activation of PKG. The above results were extended at the behavioral level, showing that upregulation of PKG either indirectly via PDE5 inhibition or directly via a PKG activator could rescue deficits of short-term reference memory and contextual memory resulted from intrahippocampal injection of oTau. Importantly, elevation of cGMP levels restored CREB phosphorylation after LTP induction in the presence of oTau. These results provide novel evidence showing that agents acting on the NO cascade could be beneficial in counteracting plasticity and memory decline encountered in tauopathies.

Finally in chapter 6, despite of confirming the previous observation that oTau could cause faster decline in synaptic plasticity and blockage of memory formation, we also showed that upregulation of cAMP/PKA signaling could ameliorate LTP and spatial memory impairments. At the molecular level, we demonstrated that intrahippocampal administration of oTau hampered trafficking of GluA1-AMPARs, while concomitant increase in cAMP signaling via PDE4 inhibition was able to compensate against oTau-induced impairments in AMPARs trafficking. In conclusion, our study provides a link between tau pathology and glutamatergic system and additionally suggests that interventions that target the cAMP/PKA signaling pathway could be promising in diseases characterized by tau aggregates. 